\title{
openheart Impact of changes in heart rate with age on all-cause death and cardiovascular events in 50-year-old men from the general population
}

\author{
Xiao-jing Chen, ${ }^{\circ 1,2}$ Salim Bary Barywani, ${ }^{3}$ Per-Olof Hansson, ${ }^{4}$ \\ Erik Östgärd Thunström, ${ }^{3}$ Annika Rosengren, ${ }^{5}$ Constantinos Ergatoudes, ${ }^{3}$ \\ Zacharias Mandalenakis, ${ }^{6}$ Kenneth Caidahl, ${ }^{7}$ Michael Lx Fu ${ }^{3}$
}

To cite: Chen X, Barywani SB, Hansson P-0, et al. Impact of changes in heart rate with age on all-cause death and cardiovascular events in 50-year-old men from the general population. Open Heart 2019;6:e000856. doi:10.1136/ openhrt-2018-000856

Received 15 May 2018 Revised 2 December 2018 Accepted 20 January 2019

Check for updates

(C) Author(s) (or their employer(s)) 2019. Re-use permitted under CC BY-NC. No commercial re-use. See rights and permissions. Published by BMJ.

For numbered affiliations see end of article.

Correspondence to Dr Salim Bary Barywani; salim. barywani@vgregion.se

\section{ABSTRACT}

Background Resting heart rate (RHR), a known cardiovascular risk factor, changes with age. However, little is known about the association between changes in RHR and the risk of cardiovascular events. The purpose of this study was therefore to assess the impact of RHR at baseline, and the change in RHR over time, on the risk of all-cause death and cardiovascular events.

Design A random population sample of men born in 1943 who were living in Gothenburg, Sweden was prospectively followed for a 21-year period.

Methods Participants were examined three times: first in 1993 and then re-examined in 2003 and 2014. At each visit, a clinical examination, an ECG and laboratory analyses were performed. Change in RHR between 1993 and 2003 was defined as a decrease if RHR decreased by 5 beats per minute (bpm), an increase if RHR increased by $5 \mathrm{bpm}$ or stable if the RHR change was $\leq 4 \mathrm{bpm}$ ).

Results Participants with a baseline RHR of $>75 \mathrm{bpm}$ in 1993 had about a twofold higher risk of all-cause death (HR 2.3, Cl 1.2 to 4.7, $p=0.018$ ), cardiovascular disease (CVD) (HR 1.8, Cl 1.1 to 3.0, $\mathrm{p}=0.014$ ) and coronary heart disease (CHD) (HR 2.2, Cl 1.1 to 4.5, $p=0.025$ ) compared with those with $\leq 55 \mathrm{bpm}$ in 1993. Participants with a stable RHR between 1993 and 2003 had a 44\% decreased risk of CVD (HR 0.56, Cl 0.35 to 0.87, p=0.011) compared with participants with an increasing RHR. Furthermore, every beat increase in heart rate from 1993 was associated with a $3 \%$ higher risk for all-cause death, $1 \%$ higher risk for CVD and $2 \%$ higher risk for CHD.

Conclusion High RHR was associated with an increased risk of death and cardiovascular events in men from the general population. Moreover, individuals with an increase in RHR between 50 and 60 years of age had worse outcome.

\section{INTRODUCTION}

Cardiovascular diseases (CVDs) are still the major cause of premature death in middleaged populations. Resting heart rate (RHR) is known to be inversely related to average life span in homoeothermic mammals. ${ }^{1}$ Previous studies have demonstrated an association

\section{Key messages}

What is already known about this subject?

- Resting heart rate (RHR) changes with age and is a known cardiovascular risk factor.

What does this study add?

- Men with a RHR of over 75 beats per minute at 50 years of age have twice as high risk of all-cause death, cardiovascular disease and coronary heart disease during 21 years of follow-up compared with men with RHR of 55 beats per minute or below.

- The RHR at baseline and an increased RHR over time, compared with no change, are associated with increased risk of cardiovascular events.

How might this impact on clinical practice?

- This study is clinically relevant in the sense that it can be misleading to use only a single RHR value to assess cardiovascular risk over a long period.

- Our findings demonstrate that both the RHR at baseline and an increase in RHR over time, as opposed to unchanged, were associated with worse cardiovascular outcome.

between elevated RHR and increased incident of CVDs and both all-cause and cardiovascular mortality in the general population. ${ }^{2-17}$ Sharashova et al reported an independent positive association between RHR and the risk of incident myocardial infarction, atrial fibrillation and both total death and cardiovascular death in men from a general population in Norway. ${ }^{2}$ Moreover, Aune et al observed a positive association between RHR and risk of CVD and all-cause mortality. ${ }^{3}$ However, in a meta-analysis, Zhang and coworkers showed that RHR was an independent predictor of coronary artery disease, stroke, sudden death and non-CVDs over all of the studies combined; however, when the analyses included only studies of general populations, RHR was not associated with 
sudden death. ${ }^{5}$ The risk for cardiovascular morbidity and mortality begins to increase in middle age ${ }^{18}$ and in the meantime RHR changes with age. Moreover, the impact of the incremental change in RHR on incident cardiovascular morbidity and mortality in middle-aged general populations has not been adequately studied. Therefore, the present study aimed to investigate the impact of RHR at baseline and the change in RHR over time on the risk of cardiovascular morbidity and mortality in a middleaged general population.

\section{METHODS}

\section{Study population}

'The study of Men Born in 1943' is a longitudinal, prospective, population-based study of men born in 1943 and living in the city of Gothenburg in western Sweden at the age of 50 years $^{19}$. From the Swedish Population Register, a random sample of $50 \%$ of all men born in 1943 and living in Gothenburg received an invitation to attend the study in $1993(\mathrm{n}=1450)$. Of those invited, 798 $(55 \%)$ accepted to participate in the investigation that included questionnaires and physical examination procedures. At the second examination in 2003, 749 of the 798 men who were still alive were invited; of these, 654 $(82 \%)$ accepted to be re-examined. In the third examination in 2014, 536 of 688 men still alive $(78 \%)$ attended this examination. The same methodology was used in all three examinations. The study complies with the Declaration of Helsinki. The Gothenburg Regional Research Ethics Board approved the study and informed consent

\begin{tabular}{|c|c|c|c|c|c|}
\hline Parameters & $\begin{array}{l}\text { RHR<55 } \\
(n=109) \\
\end{array}$ & $55 \leq \mathrm{RHR}<65(\mathrm{n}=249)$ & $\begin{array}{l}65 \leq \mathrm{RHR}<75 \\
(\mathrm{n}=248)\end{array}$ & $\begin{array}{l}\text { RHR } \geq 75 \\
(n=192)\end{array}$ & $P$ value \\
\hline \multicolumn{6}{|l|}{ Lifestyle } \\
\hline Never smokers, $n(\%)$ & $47(43.1)$ & $88(35.3)$ & $73(29.4)$ & $50(26.0)$ & 0.001 \\
\hline $\begin{array}{l}\text { Previous smokers, } \\
\mathrm{n}(\%)\end{array}$ & $39(35.8)$ & $101(40.6)$ & $86(34.7)$ & $67(34.9)$ & 0.030 \\
\hline Current smokers, n (\%) & $23(21.1)$ & $60(24.1)$ & $89(35.9)$ & $75(39.1)$ & 0.010 \\
\hline $\begin{array}{l}\text { Sedentary lifestyle, } \\
\mathrm{n}(\%)\end{array}$ & $9(8.3)$ & $30(12.0)$ & $43(17.3)$ & $43(22.4)$ & 0.003 \\
\hline $\begin{array}{l}\text { Sleeping time per night, } \\
\text { hour, mean } \pm S D\end{array}$ & $6.9 \pm 0.8$ & $7.0 \pm 0.8$ & $6.9 \pm 1.0$ & $7.0 \pm 1.1$ & 0.709 \\
\hline Mental stress, $\mathrm{n}(\%)$ & $10(9.3)$ & $31(12.5)$ & $51(20.6)$ & $32(16.8)$ & 0.020 \\
\hline \multicolumn{6}{|l|}{ Clinical characteristics } \\
\hline $\mathrm{BMI}, \mathrm{kg} / \mathrm{m}^{2}$, mean $\pm \mathrm{SD}$ & $25.5 \pm 2.9$ & $26.1 \pm 3.3$ & $26.4 \pm 3.2$ & $26.6 \pm 4.0$ & 0.026 \\
\hline $\begin{array}{l}\text { Waist circumference, } \\
\mathrm{cm}, \text { mean } \pm S D\end{array}$ & $92.2 \pm 8.7$ & $94.0 \pm 8.9$ & $95.9 \pm 8.6$ & $97.5 \pm 11.0$ & $<0.001$ \\
\hline $\begin{array}{l}\text { Systolic BP, mm Hg, } \\
\text { mean } \pm S D\end{array}$ & $124.5 \pm 15.2$ & $126.5 \pm 17.4$ & $128.5 \pm 16.5$ & $134.1 \pm 17.4$ & $<0.001$ \\
\hline $\begin{array}{l}\text { Diastolic BP, mm Hg, } \\
\text { mean } \pm S D\end{array}$ & $81.4 \pm 10.8$ & $82.7 \pm 9.9$ & $85.1 \pm 10.0$ & $87.4 \pm 11.3$ & $<0.001$ \\
\hline \multicolumn{6}{|l|}{ Medical history, n (\%) } \\
\hline Hypertension & $7(6.5)$ & $13(5.2)$ & $13(5.2)$ & $17(8.9)$ & 0.371 \\
\hline Hyperlipidaemia, & $4(3.7)$ & $5(2.0)$ & $8(3.2)$ & $17(8.9)$ & 0.005 \\
\hline Atrial fibrillation & $1(1)$ & $3(1)$ & $2(1)$ & $3(2)$ & 0.894 \\
\hline Diabetes & 0 & $4(2)$ & $6(2.4)$ & $9(4.7)$ & 0.206 \\
\hline Stroke & $1(1)$ & 0 & $1(0.4)$ & 0 & 0.349 \\
\hline Lung disease & $9(8.3)$ & $18(7.2)$ & $16(6.5)$ & $13(6.8)$ & 0.937 \\
\hline \multicolumn{6}{|c|}{ Laboratory characteristics, mean $\pm S D$} \\
\hline Cholesterol, mmol/L & $5.7 \pm 0.9$ & $5.9 \pm 1.1$ & $5.9 \pm 1.0$ & $6.1 \pm 1.1$ & 0.016 \\
\hline Triglyceride, mmol/L & $1.2 \pm 0.7$ & $1.6 \pm 1.0$ & $1.8 \pm 1.3$ & $1.9 \pm 1.2$ & $<0.001$ \\
\hline $\mathrm{HDL}, \mathrm{mmol} / \mathrm{L}$ & $1.43 \pm 0.4$ & $1.31 \pm 0.3$ & $1.28 \pm 0.3$ & $1.26 \pm 0.3$ & $<0.001$ \\
\hline Creatinine, $\mathrm{mmol} / \mathrm{L}$ & $90.4 \pm 6.9$ & $90.8 \pm 11.5$ & $91.5 \pm 9.5$ & $91.1 \pm 10.0$ & 0.766 \\
\hline NT-pro-BNP, pg/mL & $41.2 \pm 45.8$ & $32.8 \pm 31.1$ & $36.3 \pm 51.2$ & $34.4 \pm 43.3$ & 0.403 \\
\hline IL-6 & $2.2 \pm 1.6$ & $2.6 \pm 2.0$ & $2.7 \pm 2.7$ & $3.5 \pm 6.7$ & 0.015 \\
\hline
\end{tabular}

BMI, body mass index; BP, blood pressure; Bpm, beats per min; HDL, high-density lipoprotein; IL-6, interleukin 6; NT-pro-BNP, $\mathrm{N}$-terminal prohormone of brain natriuretic peptide; $\mathrm{RHR}$, resting heart rate. 
has been obtained from the participants. The study is registered in Clinical Trials.gov (Identifier number: NCT03138122).

\section{Data collection}

At the baseline examination and at each re-examination, medical history of each participant was obtained and a physical examination was performed. In the 2014 visit, all study participants also underwent an echocardiography examination. Fasting venous blood samples were drawn in the morning and plasma levels of total serum cholesterol, triglycerides, Creatinine, high-density lipoprotein, N-terminal prohormone of brain natriuretic peptide (NT-pro-BNP) and interleukin 6 were analysed using standard laboratory procedures. Blood pressure was recorded in the right arm in the sitting position by a mercury sphygmomanometer. Body mass index (BMI) was calculated as weight $(\mathrm{kg})$ divided by height squared $\left(\mathrm{m}^{2}\right)$. Before the examination, all participants had completed questionnaires addressing their smoking habits, physical activity and family history of CVD, previous diseases and mental stress. Information on smoking habits was obtained by questionnaire. Participants were classified as never smokers, previous smokers or current smokers. Physical activity during leisure time was introduced at each examination and graded as follows: (1) mainly sedentary, (2) moderate exercise during leisure time, (3) regular exercise and training, (4) hard exercise or competitive sports. For analysis, grades 2, 3 and 4 were combined and grade 1 was defined as a sedentary lifestyle. Mental stress, with six response options, was defined as feeling tense, irritable or filled with anxiety or having sleeping difficulties as a result of conditions at work or at home: (1) never

Table 2 Baseline characteristics (1993) according to different patterns of heart rate change over time

\begin{tabular}{|c|c|c|c|c|}
\hline Parameters & $\begin{array}{l}\text { Increased HR group } \\
(n=111)\end{array}$ & $\begin{array}{l}\text { Stable HR group } \\
(\mathrm{n}=206)\end{array}$ & $\begin{array}{l}\text { Decreased HR group } \\
(\mathrm{n}=337)\end{array}$ & $P$ value \\
\hline $\begin{array}{l}\text { RHR change from } 1993 \text { to } 2013 \\
\text { mean } \pm \text { SD }\end{array}$ & $+(10 \pm 6)$ & $(4 . \pm 2)$ & $-(13 \pm 7)$ & $<0.001$ \\
\hline \multicolumn{5}{|l|}{ Lifestyle } \\
\hline Never smoker, n (\%) & 41 (36.9) & $74(35.9)$ & $107(31.8)$ & 0.454 \\
\hline Previous smoker, $\mathrm{n}(\%)$ & $38(34.2)$ & $83(40.3)$ & $128(38.0)$ & 0.432 \\
\hline Current smoker, $\mathrm{n}(\%)$ & $32(28.8)$ & $49(23.8)$ & $102(30.3)$ & 0.532 \\
\hline Sedentary lifestyle, $n(\%)$ & $10(9.0)$ & $26(12.6)$ & $55(16.3)$ & 0.126 \\
\hline $\begin{array}{l}\text { Sleeping time per night, hour, } \\
\text { mean } \pm S D\end{array}$ & $7.0 \pm 1.0$ & $7.0 \pm 0.9$ & $6.9 \pm 1.0$ & 0.994 \\
\hline Mental stress, n (\%) & 17 (15.5) & $25(12.2)$ & $52(15.5)$ & 0.543 \\
\hline \multicolumn{5}{|l|}{ Clinical characteristics } \\
\hline $\mathrm{BMI}, \mathrm{kg} / \mathrm{m}^{2}$, mean $\pm \mathrm{SD}$ & $25.8 \pm 3.3$ & $25.8 \pm 3.1$ & $26.6 \pm 3.4$ & 0.014 \\
\hline Waist circumference, $\mathrm{cm}$, mean $\pm \mathrm{SD}$ & $93.1 \pm 8.4$ & $94.0 \pm 8.6$ & $96.6 \pm 9.3$ & $<0.001$ \\
\hline Systolic BP, mm Hg, mean $\pm S D$ & $128.1 \pm 17.8$ & $127.0 \pm 16.2$ & $130.1 \pm 16.8$ & 0.096 \\
\hline Diastolic BP, mm Hg, mean $\pm \mathrm{SD}$ & $84.2 \pm 11.4$ & $83.0 \pm 9.7$ & $84.9 \pm 10.6$ & 0.116 \\
\hline \multicolumn{5}{|l|}{ Medical history, n (\%) } \\
\hline Hypertension & $16(14.5)$ & $30(9.8)$ & $39(11.6)$ & 0.446 \\
\hline Hyperlipidaemia & $16(14.5)$ & $20(9.8)$ & $33(9.8)$ & 0.334 \\
\hline Atrial fibrillation & $1(1)$ & $3(1)$ & $2(1)$ & 0.894 \\
\hline Diabetes & $2(1.8)$ & $2(1.0)$ & $9(2.7)$ & 0.388 \\
\hline Stroke & 0 & $1(0.5)$ & 0 & 0.336 \\
\hline Lung disease & $4(3.6)$ & $18(8.7)$ & $18(5.3)$ & 0.133 \\
\hline \multicolumn{5}{|l|}{ Laboratory characteristics, mean $\pm S D$} \\
\hline Cholesterol, mmol/L & $5.9 \pm 1.0$ & $5.8 \pm 1.0$ & $5.9 \pm 1.0$ & 0.216 \\
\hline Triglyceride, $\mathrm{mmol} / \mathrm{L}$ & $1.7 \pm 1.0$ & $1.5 \pm 0.9$ & $1.7 \pm 1.0$ & 0.252 \\
\hline $\mathrm{HDL}, \mathrm{mmol} / \mathrm{L}$ & $1.3 \pm 0.3$ & $1.4 \pm 0.4$ & $1.3 \pm 0.3$ & 0.066 \\
\hline Creatinine, $\mathrm{mmol} / \mathrm{L}$ & $91.1 \pm 11.2$ & $90.8 \pm 10.0$ & $91.6 \pm 9.9$ & 0.605 \\
\hline NT-pro-BNP, pg/mL & $37.5 \pm 46.2$ & $34.9 \pm 43.6$ & $34.5 \pm 42.3$ & 0.829 \\
\hline IL-6 & $2.1 \pm 1.3$ & $2.4 \pm 1.4$ & $2.8 \pm 2.4$ & 0.002 \\
\hline
\end{tabular}

BP, blood pressure; HDL, high-density lipoprotein; IL-6, interleukin 6; NT-pro-BNP, N-terminal prohormone of brain natriuretic peptide. 


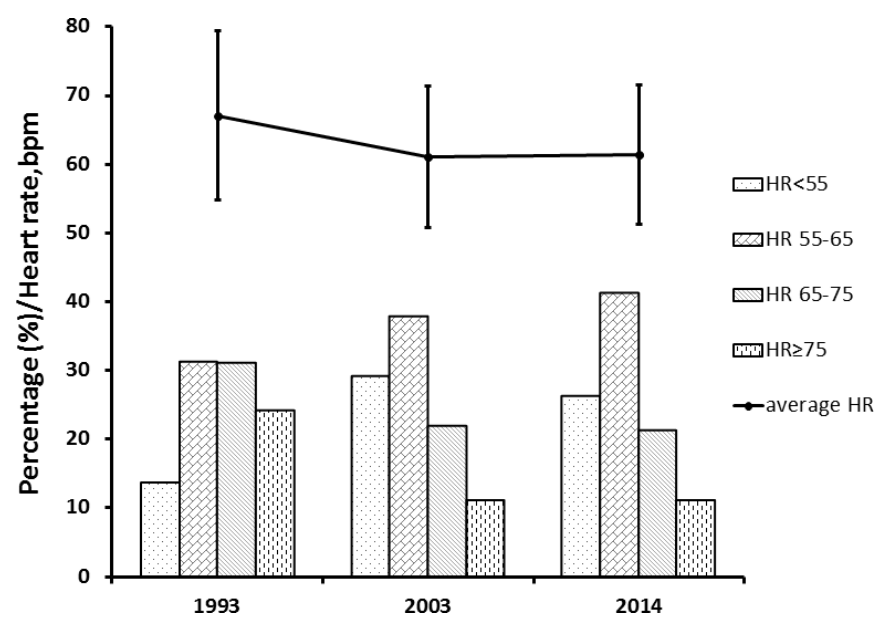

Figure 1 Trend of heart rate distributions from 1993, 2003 to 2014 . I bars represent the SD. RHR, resting heart rate.

experienced stress, (2) one period of stress ever, (3) some periods in the past 5 years, (4) repeated periods during the past 5 years, (5) permanent stress during the past year and (6) permanent stress during the past 5 years, with 5 to 6 defined as mental stress.

\section{Measurement of resting heart rate and group classification}

Heart rate was measured by 12-lead ECG in the supine position in 1993, 2003 and 2014. Paper speed was 50 $\mathrm{mm} / \mathrm{s}$ and calibration was $1 \mathrm{mV}: 10 \mathrm{~mm}$. In 1993 and 2003, all ECGs were evaluated by one of the coauthors $(\mathrm{POH})$; in 2014, the ECGs were evaluated by one of five physicians. When evaluating the ECGs, the physician was blinded to the clinical data. The study sample was divided into four groups according to their RHR in 1993: group 1: RHR $<55$ beats per minute (bpm), group 2: RHR 56-65 bpm, group 3: RHR 66-75 bpm and group 4: RHR>75 bpm.
The change in RHR from 1993 to $2003(\Delta \mathrm{HR})$ was defined as RHR in 2003 minus RHR in 1993. We then separated the cohort into three subgroups according to $\Delta$ HR in the 10-year follow-up: (1) decreased RHR: $\Delta \mathrm{HR} \leq-5 \mathrm{bpm}$, (2) stable RHR: -5 bpm $<\Delta \mathrm{HR}<5$ bpm and (3) increased RHR: $\triangle H R \geq 5 \mathrm{bpm}$. These subgroups were compared for the outcome variables: all-cause mortality, cardiovascular disease (CVD) and coronary heart disease (CHD).

\section{Follow-up procedures and endpoints}

Participants were followed from 1 January 1993 to 31 August 2014. Outcome and clinical data were collected by reviewing medical charts, the Swedish Hospital Discharge Registry and the Swedish Death Registry for all participants from 1993 to 2014. Three major endpoints were applied in this study: CVD, CHD and all-cause mortality. The criteria used to define a CVD event were the time to first occurrence of myocardial infarction, heart failure, death resulting from CHD (410-414; I20-21), stroke, intermittent claudication, other cardiovascular deaths and revascularisation procedures. A history of CHD without hospitalisation or revascularisation did not meet our definition of CVD. CHD was defined as the first occurrence of myocardial infarction, coronary artery revascularisation and death resulting from CHD (410-414; I20-21). All endpoints were reviewed by one of five physicians.

\section{Statistical analysis}

Baseline demographic and clinical characteristics were stratified by heart rate at baseline (table 1) and according to different groups of heart rate change during follow-up (table 2). Descriptive statistics with normal distribution are presented as the mean value $\pm \mathrm{SD}$ and compared using one-way analysis of variance. Crude incidence rates were expressed as event rates, calculated as the number of

Table 3 Outcome data according to resting heart rate subgroups, 1993

\begin{tabular}{|c|c|c|c|c|c|c|c|c|c|}
\hline & \multicolumn{3}{|c|}{ All-cause death } & \multicolumn{3}{|c|}{ Cardiovascular disease } & \multicolumn{3}{|c|}{ Coronary heart disease } \\
\hline & \multirow[t]{2}{*}{$\begin{array}{l}\text { No events } \\
(\%) \\
\text { ER ( }{ }^{\star} 1000 \text { py) }\end{array}$} & \multicolumn{2}{|l|}{$\begin{array}{l}\text { HR }(95 \% \mathrm{Cl}) \\
\mathrm{P} \text { value }\end{array}$} & \multirow[t]{2}{*}{$\begin{array}{l}\text { No events (\%) } \\
\text { ER (*1000 py) }\end{array}$} & \multicolumn{2}{|l|}{$\begin{array}{l}\text { HR }(95 \% \mathrm{Cl}) \\
\mathrm{P} \text { value }\end{array}$} & \multirow[t]{2}{*}{$\begin{array}{l}\text { No events } \\
(\%) \\
\text { ER ( }{ }^{\star} 1000 \text { py) }\end{array}$} & \multicolumn{2}{|l|}{$\begin{array}{l}\text { HR }(95 \% \mathrm{Cl}) \\
\mathrm{P} \text { value }\end{array}$} \\
\hline & & Unadjusted & Adjusted & & Unadjusted & Adjusted & & Unadjusted & Adjusted \\
\hline \multirow{2}{*}{$\begin{array}{l}\text { RHR }<55 \\
(n=109)\end{array}$} & $10(9.2)$ & 1 (ref) & $1($ ref $)$ & $23(21.1)$ & 1 (ref) & 1 (ref) & $10(9.2)$ & 1 (ref) & 1 (ref) \\
\hline & 4.3 & & & 10.0 & & 0.003 & 4.3 & & 0.753 \\
\hline $\begin{array}{l}55 \leq \mathrm{RHR}<65 \\
(\mathrm{n}=249)\end{array}$ & 5.7 & 0.432 & 0.807 & 12.8 & 0.234 & 0.274 & 4.8 & 0.757 & 0.826 \\
\hline \multirow[t]{2}{*}{$\begin{array}{l}65 \leq \mathrm{RHR}<75 \\
(\mathrm{n}=248)\end{array}$} & $34(13.7)$ & 1.5 (0.8 to 3.1$)$ & $\begin{array}{l}1.3(0.6 \text { to } \\
2.6)\end{array}$ & $75(30.2)$ & 1.5 (1.0 to 2.4$)$ & $\begin{array}{l}1.4(0.9 \text { to } \\
2.2)\end{array}$ & $34(13.7)$ & 1.5 (0.8 to 3.1$)$ & $\begin{array}{l}1.1(0.5 \text { to } \\
2.4)\end{array}$ \\
\hline & 6.5 & 0.245 & 0.530 & 14.4 & 0.234 & 0.189 & 6.5 & 0.231 & 0.742 \\
\hline
\end{tabular}

Adjusted for body mass index, systolic blood pressure, smoking, sedentary lifestyle, mental stress, NT-pro-BNP and eGFR.

ER, event rate (1000 per year); NT-pro-BNP, N-terminal prohormone of brain natriuretic peptide; py, person years; RHR, resting heart rate; eGFR, estimated glomerular filtration rate. 

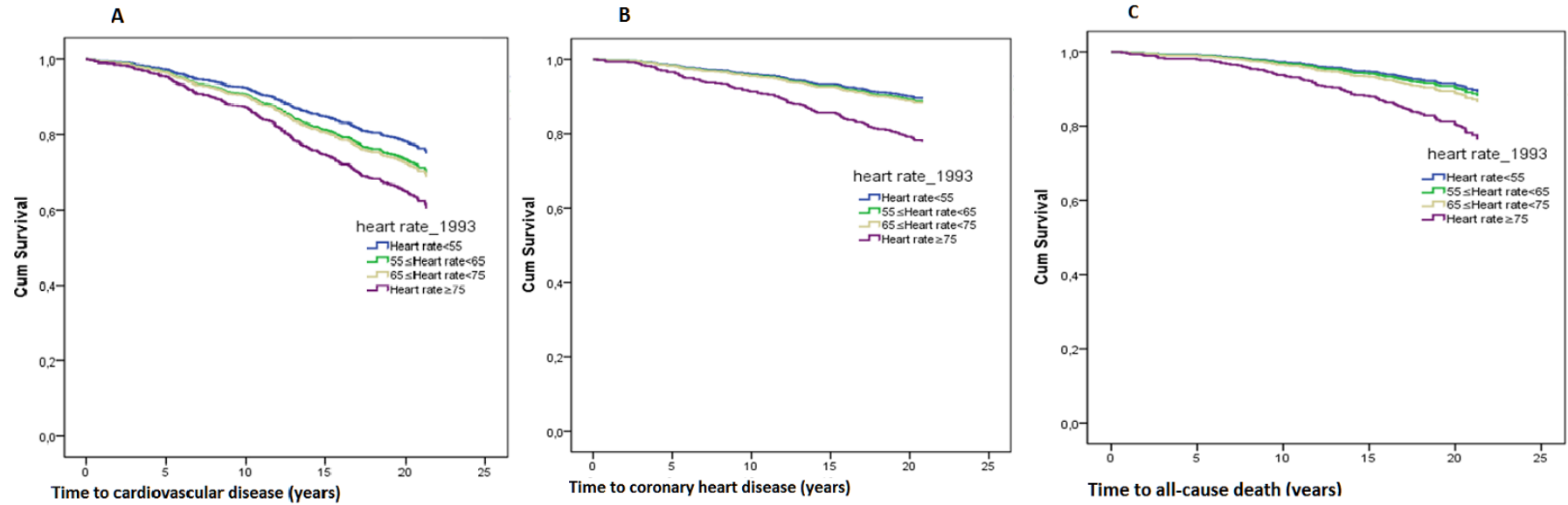

Figure 2 Adjusted risk for outcome according to different heart rate strata: (A) cardiovascular disease; (B) coronary heart disease; (C) all-cause death.

events divided by the sum of follow-up years per 1000 person-years. The categorical variables were presented as simple frequencies and percentages and compared using Pearson's $\chi^{2}$ test. All time-to-event regression analyses were based on Cox proportional hazards models. The association between the RHR and outcome was tested in models including baseline RHR as a categorical variable with adjustment for the other risk factors at baseline: BMI, systolic blood pressure, smoking, mental stress, sedentary lifestyle, NT-pro-BNP and estimated Glomerular Filtration Rate (eGFR). HRs were calculated comparing the three higher groups of the RHR with the lowest, with $95 \%$ CIs and p values. Similar models were fitted with RHR in 1993 and 2003 as a continuous variable in each instance; the HRs and 95\% CIs were calculated for each bpm increase in RHR. Similar models were used to determine the association between outcome and change in RHR during the first 10 years of follow-up. Individuals with stable and decreased RHR were compared with individuals with increased RHR. Time-to-event curves were presented by groups of the baseline RHR distribution, estimated with the Kaplan-Meier method and compared with a log-rank test.

All statistical analyses were performed using SPSS 22 statistical software (SPSS, Chicago, Illinois, USA). Two-tailed tests of significance were performed for all comparisons, and the $p$ value was set at $p<0.05$.

\section{RESULTS}

\section{Baseline characteristics in 1993}

Participants in the higher RHR subgroups $(55 \leqq \mathrm{HR}<65$, $65 \leqq H R<75$ and $H R \geqq 75$ ) were more likely to be current smokers, had more often a sedentary lifestyle and mental stress, higher BMI, wider waist circumference, higher systolic and diastolic blood pressure and were more likely to have a medical history of hypertension, hyperlipidaemia and diabetes than participants in the lower RHR subgroup $(\mathrm{HR}<55)$ (table 1$)$. Baseline characteristics according to different groups of RHR change are presented in table 2 .
A

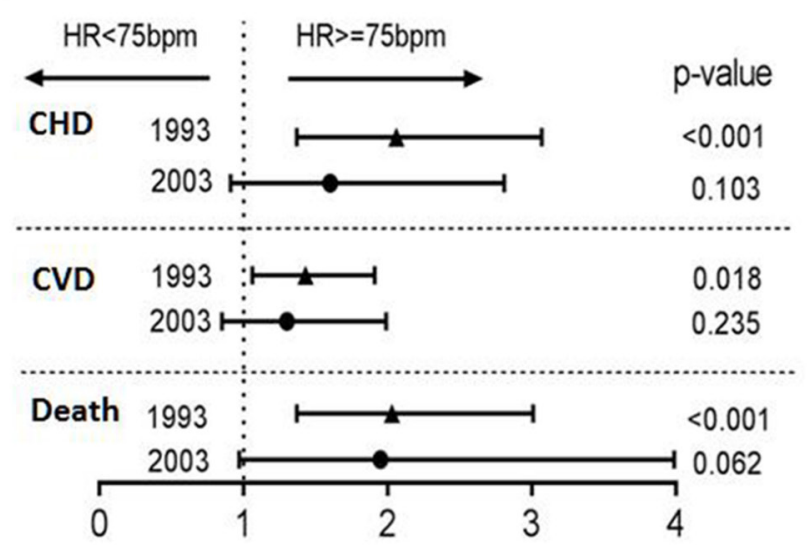

B

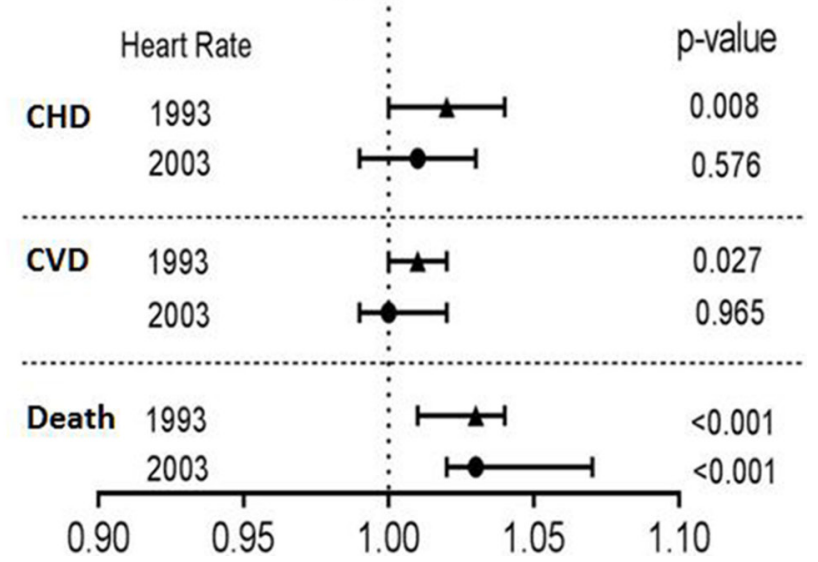

Figure 3 Risk for cardiovascular disease and all-cause death according to RHR: $(A)$ as categorical variable (HR $\geq 75$ bpm vs $\mathrm{HR}<75 \mathrm{bpm}$ ) and (B) as a continuous variable in 21 years 1993-2014 and 11 years 2003-2014. CVD, cardiovascular disease; $\mathrm{CHD}$, coronary heart disease; RHR, resting heart rate. 
Table 4 Impact of the change in resting heart rate 1993 to 2003 on outcome

\begin{tabular}{|c|c|c|c|c|c|c|c|c|c|}
\hline & \multicolumn{3}{|c|}{ All-cause death } & \multicolumn{3}{|c|}{ Cardiovascular disease } & \multicolumn{3}{|c|}{ Coronary heart disease } \\
\hline & \multirow{2}{*}{$\begin{array}{l}\text { No events } \\
(\%) \\
\text { ER (*1000 } \\
\text { py) }\end{array}$} & \multicolumn{2}{|l|}{$\begin{array}{l}\text { HR } \\
(95 \% \mathrm{CI}) \\
\text { P value }\end{array}$} & \multirow{2}{*}{$\begin{array}{l}\text { No } \\
\text { events(\%) } \\
\text { ER ( }{ }^{*} 1000 \\
\text { py) }\end{array}$} & \multicolumn{2}{|l|}{$\begin{array}{l}\text { HR } \\
\text { (95\% CI) } \\
\text { P value }\end{array}$} & \multirow{2}{*}{$\begin{array}{l}\text { No } \\
\text { events(\%) } \\
\text { ER }\left({ }^{*} 1000\right. \\
\text { py) }\end{array}$} & \multicolumn{2}{|l|}{$\begin{array}{l}\text { HR } \\
(95 \% \mathrm{Cl}) \\
\text { P value }\end{array}$} \\
\hline & & Unadjusted & Adjusted & & Unadjusted & Adjusted & & Unadjusted & Adjusted \\
\hline \multirow{2}{*}{$\begin{array}{l}\text { Increased RHR } \\
(n=111)\end{array}$} & $12(10.8)$ & $1($ ref) & 1 (ref) & $38(34.2)$ & $1($ ref) & 1 (ref) & $19(17.1)$ & $1($ ref) & 1 (ref) \\
\hline & \multicolumn{3}{|l|}{5.1} & \multicolumn{3}{|l|}{16.3} & \multicolumn{3}{|l|}{8.2} \\
\hline \multirow{2}{*}{$\begin{array}{l}\text { Unchanged } \\
\text { RHR } \\
(n=205)\end{array}$} & $15(7.3)$ & 0.65 (0.30 to & $0.71(0.32$ & \multirow{2}{*}{$\begin{array}{l}44(21.4) \\
10.2\end{array}$} & 0.54 (0.35 to & $0.56(0.35$ & \multirow{2}{*}{$\begin{array}{l}20(9.7) \\
4.6\end{array}$} & 0.53 (0.28 to & $0.64(0.32$ \\
\hline & 3.4 & $\begin{array}{l}1.39) \\
0.265\end{array}$ & $\begin{array}{l}\text { to } 1.61 \text { ) } \\
0.417\end{array}$ & & $\begin{array}{l}0.83) \\
0.005\end{array}$ & $\begin{array}{l}\text { to } 0.87 \text { ) } \\
0.011\end{array}$ & & $\begin{array}{l}0.99) \\
0.047\end{array}$ & $\begin{array}{l}\text { to } 1.25) \\
0.636\end{array}$ \\
\hline \multirow{3}{*}{$\begin{array}{l}\text { Decreased RHR } \\
(\mathrm{n}=338)\end{array}$} & $28(8.3)$ & 0.75 (0.38 to & $0.76(0.37$ & \multirow{3}{*}{$\begin{array}{l}111(32.9) \\
15.6\end{array}$} & $0.93(0.65$ to & $0.91(0.61$ & \multirow{3}{*}{$\begin{array}{l}55(16.3) \\
7.8\end{array}$} & 0.95 (0.57 to & $1.08(0.60$ \\
\hline & 3.9 & 1.47) & to 1.59$)$ & & 1.35) & to 1.34 ) & & $1.60)$ & to 1.92$)$ \\
\hline & & 0.394 & 0.467 & & 0.710 & 0.622 & & 0.952 & 0.808 \\
\hline
\end{tabular}

Adjusted for body mass index, systolic blood pressure, smoking, sedentary lifestyle, mental stress, NT-pro-BNP and eGFR.

$\mathrm{ER}$, event rate (1000 per year); NT pro BNP, N-terminal prohormone of brain natriuretic peptide; py, person years;; RHR, resting heart rate.

\section{Trend of the resting heart rate from 1993 to 2014}

The average RHR decreased from $67 \pm 12$ bpm in 1993 to $61 \pm 10 \mathrm{bpm}$ in 2003 and remained unchanged in 2014. Participants with RHR $\leq 55$ bpm were almost twice as many in $2003(29.2 \%)$ and $2014(26.3 \%)$ compared with 1993 $(13.7 \%)$. In contrast, participants with RHR $>75 \mathrm{bpm}$ were significantly fewer in $2003(11.2 \%)$ and $2014(11.2 \%)$ compared with 1993 (24.1\%) (figure 1).

\section{The relationship between baseline heart rate in 1993 and the outcome}

Of the 798 male participants included in the analysis, 119 $(14.9 \%)$ died before the age of 71 years; 237 (29.7\%) participants experienced CVD and 113 (14.2\%) experienced CHD during a follow-up of 21 years. When the population was divided into subgroups based on the 1993 RHR, the incidence of all-cause death, CVD and CHD were highest in participants with high RHR (table 3, figure 2) RHR was also analysed as a continuous variable at two periods: for 21 years from 1993 to 2014 and

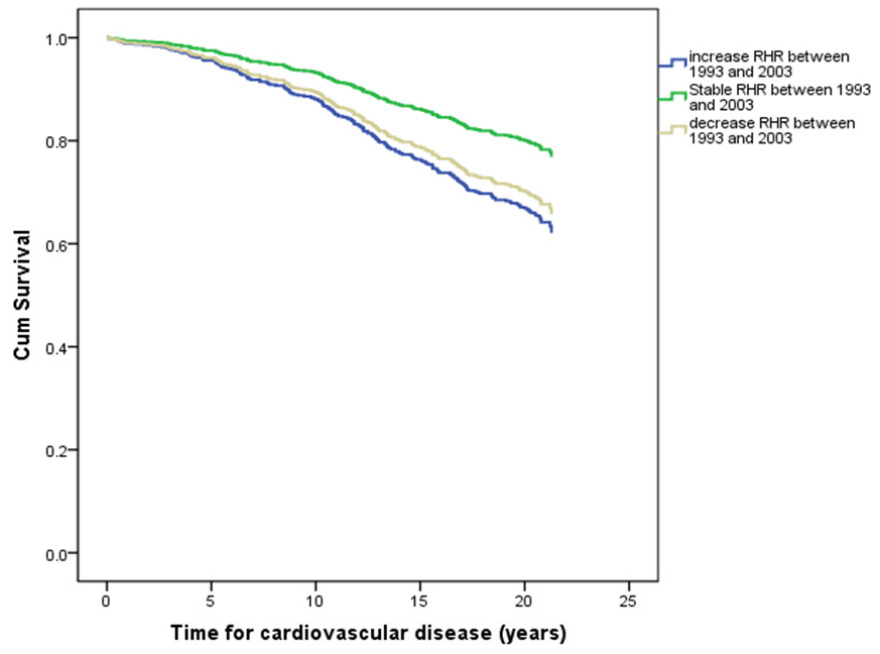

Figure 4 Adjusted overall risk for cardiovascular disease according to changes in heart rate. RHR, resting heart rate. during 11 years from 2003 to 2014 (figure 3). We found that every increase in beat in RHR from 1993 was associated with a $3 \%$ higher risk for all-cause death (HR 1.03, 95\% CI 1.01 to $1.04, \mathrm{p}<0.001$ ), a $1 \%$ higher risk for CVD (HR $1.01,95 \%$ CI 1.00 to $1.02, \mathrm{p}=0.027$ ) and a $2 \%$ higher risk for CHD (HR 1.02, 95\% CI 1.01 to $1.04, \mathrm{p}=0.008$ ). Moreover, a trend that higher RHR from 1993 increased the risk of all-cause death, CVD and CHD was observed, whereas the higher RHR from 2003 increased only the risk of all-cause death.

Men with the highest RHR (>75 bpm) in $1993 \mathrm{had}$ a more than twofold increased risk of all-cause death compared with those with $\leq 55 \mathrm{bpm}$ in 1993 (HR 2.34, 95\% CI 1.16 to $4.74, \mathrm{p}=0.018$ ) in the adjusted Cox regression models. Similar results were found for CVD (HR 1.82, $95 \%$ CI 1.13 to 2.95, $\mathrm{p}=0.014$ ) and CHD (HR 2.24, 95\% CI 1.11 to $4.54, \mathrm{p}=0.025$ ) (table 4 ).

\section{Impact of the changes in the resting heart rate on outcome}

Of the 654 men who participated in the 2003 examination, 111 had increased RHR (increased $\geq 5 \mathrm{bpm}$ ) since 1993, 205 with a relatively unchanged RHR since 1993 and 338 had a decreased RHR (decreased $\leq 5 \mathrm{bpm}$ ).

Cox proportional hazard models showed that individuals with a stable RHR from 1993 to 2003 had a 44\% lower risk of CVD (HR $0.56,95 \%$ CI 0.35 to $0.87, \mathrm{p}=0.011$ ) compared with those with increased RHR. Moreover, individuals with decreased RHR appeared to have a lower risk of CVD than those with increased RHR though the risk was not statistically significant. There was also a non-significant trend towards higher all-cause mortality in the participants with increased RHR compared with those with unchanged or decreased RHR (table 4, figure 4).

\section{DISCUSSION}

In a randomly selected sample of men born in 1943 in Gothenburg from the general population, we found that baseline RHR was an independent risk factor of all-cause 
death, CVD and CHD during a 21-year follow-up, and that increased RHR between 50 and 60 years of age was associated with an increased risk of CVD compared with individuals with stable RHR.

Our study is unique in this regard because the follow-up was 21 years with three separate examination occasions allowing us for the first time to determine the relevance of the change in RHR over time. Our finding that increased RHR was related to an increased risk of CVD is particularly noteworthy given that RHR may change during the life course. For the first time, our results demonstrate an association between the mode of RHR change and outcome. Despite a relatively lower baseline RHR (59 \pm 10$)$, individuals with increasing RHR during follow-up had the worst outcome compared with those with a stable RHR. This finding is clinically relevant in that it highlights that it may be misleading to use only a single RHR value to assess the risk over long periods, as is the case in the Tromsø study. ${ }^{2}$ Both the follow-up duration and change in RHR are important factors.

\section{Possible mechanisms}

RHR may affect the outcome through various mechanisms. High RHR could increase haemodynamic stress and shorten the diastolic phase, which could increase mechanical load, shear stress, blood pressure and cardiac work, thereby increasing oxygen consumption. These effects could cause coronary atherosclerosis and myocardial ischaemia. ${ }^{20-22}$ High RHR is also a marker of sympathetic overactivity, which is associated with an increased risk of cardiovascular events. ${ }^{23-25}$ Sympathetic overactivity may also confer an increased risk of obesity that could induce insulin resistance, higher levels of uric acid, lipid abnormalities and hypertension. ${ }^{20}$ These adverse events associated with sympathetic overactivity may therefore account for the observed association between high RHR and increased risk of both cardiovascular and non-cardiovascular events. One main concern lies in whether a high RHR is an independent predictor given that higher heart rates coexist with traditional risk factors of cardiovascular disease and poor health status. ${ }^{16}{ }^{26-29}$ However, the present results were adjusted for conventional risk factors.

\section{Strengths and limitations}

The strengths of this study were the randomly selected cohort from the general population, the prospective long longitudinal (21-year follow-up) design and the repeated heart rate measurement after 10 years. Moreover, we had a high attendance rate and information on a number of cardiovascular risk factors, which allowed us to adjust the regression models for these factors. The limitations were: (1) only men were included, (2) the participants' age may have caused age itself to be a strong competing risk factor, (3) and the relatively low uptake.

\section{CONCLUSION}

In this study of men followed between 50 and 71 years of age, our findings demonstrate that both the RHR $>75$ beat per minute at baseline and an increase in RHR over time compared with unchanged RHR had worse cardiovascular outcome.

\section{Author affiliations}

${ }^{1}$ Sahlgrenska Academy, University of Gothenburg, Gothenburg, Sweden

${ }^{2}$ Department of Cardiology, Sichuan University West China Hospital, Chengdu, China

${ }^{3}$ Department of Cardiology, Sahlgrenska Academy. University of Gothenburg, Gothenburg, Sweden

${ }^{4}$ Department of Molecular and Clinical Medicine/ Emergency and Cardiovascular Medicine Cardiology, Sahlgrenska Academy, Gothenburg, Sweden

${ }^{5}$ Sahlgrenska University Hospital Ostra, Goteborg, Sweden

${ }^{6}$ Molecular and Clinical Medicine, Goteborgs universitet Sahlgrenska Akademin, Goteborg, Sweden

${ }^{7}$ Molecular Medicine and Surgery, Karolinska Institutet, Stockholm, Sweden

Contributors SBB, XC, P-OH, ET, AR, CE, ZM, KG and MLF conceived of the presented idea. SBB, XC and MLF developed the theory and performed the computations. SBB, XC and MLF verified the analytical methods. All authors discussed the results and contributed to the final manuscript. SBB is responsible for the overall content as guarantor.

Funding The study was financed by grants from the Swedish state under the agreement between the 14 Swedish government and the county councils, the ALF agreement $(73400,447561,726481)$, the 15 Swedish Heart and Lung Foundation and the Swedish Research Council (SIMSAM).

Competing interests None declared.

Patient consent for publication Not required.

Provenance and peer review Not commissioned; externally peer reviewed.

Open access This is an open access article distributed in accordance with the Creative Commons Attribution Non Commercial (CC BY-NC 4.0) license, which permits others to distribute, remix, adapt, build upon this work non-commercially, and license their derivative works on different terms, provided the original work is properly cited, appropriate credit is given, any changes made indicated, and the use is non-commercial. See: http://creativecommons.org/licenses/by-nc/4.0/.

\section{REFERENCES}

1. Zhang GQ, Zhang W. Heart rate, lifespan, and mortality risk. Ageing Res Rev 2009;8:52-60.

2. Sharashova E, Wilsgaard T, Mathiesen EB, et al. Resting heart rate predicts incident myocardial infarction, atrial fibrillation, ischaemic stroke and death in the general population: The Tromsø study. J Epidemiol Community Health 2016;70:902-9.

3. Aune D, Sen A, ó'Hartaigh B, et al. Resting heart rate and the risk of cardiovascular disease, total cancer, and all-cause mortality - a systematic review and dose-response meta-analysis of prospective studies. Nutr Metab Cardiovasc Dis 2017;27:504-17.

4. Li K, Yao C, Yang X, et al. Effect of resting heart rate on all-cause mortality and cardiovascular events according to age. J Am Geriatr Soc 2017;65:989-94.

5. Zhang D, Wang W, Li F. Association between resting heart rate and coronary artery disease, stroke, sudden death and noncardiovascular diseases: a meta-analysis. CMAJ 2016;188:E38 4-E392.

6. Custodis F, Roggenbuck U, Lehmann N, et al. Resting heart rate is an independent predictor of all-cause mortality in the middle aged general population. Clin Res Cardiol 2016;105:601-12.

7. Li Y. Association between resting heart rate and cardiovascular mortality: evidence from a meta-analysis of prospective studies. Int $J$ Clin Exp Med 2015;15:153-39.

8. Zhang D, Shen X, Qi X. Resting heart rate and all-cause and cardiovascular mortality in the general population: a meta-analysis. CMAJ 2016;188:E53-E63.

9. Wang A, Chen S, Wang C, et al. Resting heart rate and risk of cardiovascular diseases and all-cause death: the Kailuan study. PLoS One 2014;9:e110985.

10. Jensen MT, Suadicani P, Hein $\mathrm{HO}$, et al. Elevated resting heart rate, physical fitness and all-cause mortality: a 16-year follow-up in the Copenhagen male study. Heart 2013;99:882-7. 
11. Jensen MT, Marott JL, Allin $\mathrm{KH}$, et al. Resting heart rate is associated with cardiovascular and all-cause mortality after adjusting for inflammatory markers: the Copenhagen City Heart study. Eur J Prev Cardiol 2012;19:102-8.

12. Boudoulas KD, Borer JS, Boudoulas H. Heart rate, life expectancy and the cardiovascular system: therapeutic considerations. Cardiology 2015;132:199-212.

13. Kannel WB, Kannel C, Paffenbarger RS, et al. Heart rate and cardiovascular mortality: the Framingham study. Am Heart $J$ 1987;113:1489-94.

14. Gillum RF. The epidemiology of resting heart rate in a national sample of men and women: associations with hypertension, coronary heart disease, blood pressure, and other cardiovascular risk factors. Am Heart J 1988;116:163-74.

15. Nanchen D, Leening MJG, Locatelli I, et al. Resting heart rate and the risk of heart failure in healthy adults: the Rotterdam study. Circ Heart Fail 2013:6:403-10.

16. Cooney MT, Vartiainen E, Laatikainen $\mathrm{T}$, et al. Elevated resting heart rate is an independent risk factor for cardiovascular disease in healthy men and women. Am Heart J 2010;159:612-9.

17. Opdahl A, Ambale Venkatesh B, Fernandes VRS, et al. Resting heart rate as predictor for left ventricular dysfunction and heart failure: MESA (multi-ethnic study of atherosclerosis). J Am Coll Cardiol 2014;63:1182-9.

18. Booth GL, Kapral MK, Fung K, et al. Relation between age and cardiovascular disease in men and women with diabetes compared with non-diabetic people: a population-based retrospective cohort study. The Lancet 2006;368:29-36.

19. Fu M, Rosengren A, Thunström E, et al. Although coronary mortality has decreased, cardiovascular disease rates remain high: a study comparing men born in 1913 and 1943. J Am Heart Assoc 2018;7:e008769.

20. Palatini P. Heart rate and the cardiometabolic risk. Curr Hypertens Rep 2013;15:253-9.

21. Fox K, Borer JS, Camm AJ, et al. Heart rate Working Group. resting heart rate in cardiovascular disease. J Am Coll Cardio 2007:50:823-30.

22. Palatini P. Elevated heart rate in cardiovascular diseases: a target for treatment? Prog Cardiovasc Dis 2009;52:46-60.

23. Gopinathannair R, Martins JB. Predicting sudden cardiac death in healthy humans: is there more to autonomic balance than we know? Heart Rhythm 2008;5:306-7.

24. Fox K, Borer JS, Camm AJ, et al. Resting heart rate in cardiovascular disease. J Am Coll Cardiol 2007;50:823-30.

25. Goff DC, Lloyd-Jones DM, Bennett G, et al. 2013 ACC/AHA guideline on the assessment of cardiovascular risk: a report of the American College of Cardiology/American Heart Association Task Force on practice guidelines. J Am Coll Cardiol 2014;63:2935-59.

26. Leistner DM, Klotsche J, Palm S, et al. Resting heart rate as a tool for risk stratification in primary care: does it provide incremental prognostic information? Eur J Prev Cardiol 2012;19:275-84.

27. Tverdal A, Hjellvik V, Selmer R. Heart rate and mortality from cardiovascular causes: a 12 year follow-up study of 379,843 men and women aged 40-45 years. Eur Heart J 2008;29:2772-81.

28. Feiner JR, Finlay-Morreale HE, Toy P, et al. High oxygen partial pressure decreases anemia-induced heart rate increase equivalent to transfusion. Anesthesiology 2011;115:492-8.

29. Morton LM, Cahill J, Hartge P. Reporting participation in epidemiologic studies: a survey of practice. Am J Epidemiol 2006;163:197-203. 